\title{
CHANGING PERCEPTION OF LUXURY BRANDING \\ IN INDIAN CONTEXT
}

\section{HEMANTHA. Y}

Research Scholar, Bharathiar University, Coimbatore, India

\begin{abstract}
Luxury retailers are eyeing Indian market as it is fast growing economy in terms of rising urbanization, patterned customers which is fast changing and purchasing power of customers. In this line, retailers are exhibiting plethora of luxury merchandise which are foreign brands in Tier-I City like New Delhi, Mumbai and Bangalore city. At the same time, luxury brands are growing at a faster pace with the adoption of the $E$ - business model. This paper presents the luxury branding practices which adopt both models of business formats i.e., Brick and Mortar (Physical Stores) and Click and Mortar (E-business or online stores). At the same time, paper addresses the changes in luxury marketing mix. KEYWORDS: Luxury Brands, Luxury Marketing Mix, Retail, Luxury Market \& E-Business
\end{abstract}

Received: Jun 15, 2019; Accepted: Jul 05, 2019; Published: Jul 23, 2019; Paper Id.: IJRMRDEC20191

\section{INTRODUCTION}

Quick Facts of the Term 'Luxury' and 'Luxury Branding'

Before embarking into the term 'Luxury' it is evident from the history of India that Luxury is not new phenomenon which is derived from the royal lifestyle of the Indian Rulers across the country who had refined tastes and connoisseurs of Luxury. In business reports and academic literatures, the term luxury and luxury branding often appears which is derived from Latin term 'luxus' which means opulence, indulgence. Moreover, it is noteworthy to mention that when necessity ends, luxury begins as quoted by Coco Chanel a French Fashion Designer and business woman (http://www.quoteauthors.com.coco-chanel-quotes/). Further, Luxury can be incorporated in any of these aspects such as a moment, an experience, special fragrance, High end Apparel/Fashion, Shoes etc., Further, luxury doesn't necessarily have to be expensive.

The Oxford Advanced Learner's Dictionary defines luxury as to enjoy special and expensive things such as food and drink, Fashion and clothing, a pleasure or an advantage that you do not often have and as a thing that is expensive and enjoyable but not essential. In the same line, Phau and Prendergast (2000) has described luxury as rareness and exclusivity in a product. Authors in luxury brand literatures specify that luxury is defined partially as pointed out by Dubois (1991). In similar fashion, many authors have contributed to the definition of luxury. In Business sense, Luxury is treated and interpreted as High Price and in social sense; it is a sign of status symbol.

After reviewing various definitions from academic literatures, a general definition of Luxury really doesn't exist the reason behind is that luxury is more subjective in nature and it is perceived differently by people in different business situations across the globe. Moreover, the perception of Luxury and associated brands adopted by luxury retailers are fast changing in prevailing business. 


\section{RATIONALE OF THE STUDY}

Limited literatures on Luxury Branding

\section{REVIEW OF LITERATURE}

The researcher has an opinion that luxury brands are highly distinct with a high degree of intangibility. In this line, Luxury retail industry develops brand which are highly distinctly from normal products. Moreover, the strategies are changing in Luxury market with huge potential for the luxury brands showcasing their business practices across major metros in India. Below are literatures which are segregated into two parts. One part addresses changing perception of Luxury Brands in India and other part is Luxury Marketing Mix of Luxury brands and associated concepts in broader perspective.

\section{Changing Perception of Luxury Brands in India - An Outlook}

Mandel et al (2006) in the article entitled 'Images of Success and the Preference for Luxury Brands' have mentioned that in the foreign market people of the United States of America often purchases Luxury products. Further, there is a increasingly trading up to luxury brands in America (Silverstein \& Fiske, 2003), regardless of their economic status, because these products provide an opportunity for the middle class to attain the perception of prosperity which is in contradiction with Indian market among people of India. So, luxury brands have to put forth a different strategy to tap the market. It is evident that the consumption of luxury products displays an individuals' wealth, differentiating them from others (Liebenstein, 1950)

Vickers and Renand (2003) in the article entitled 'The Marketing of Luxury Goods: An exploratory study-three conceptual dimensions 'have discussed about the Luxury products and the market for luxury brands has grown over the past 10 to 15 years with spectacular growth due to rapid rise in standard of living and increasing number of consumer knowledge about the product which has lead to democratisation of top-of-the-range products.

Glyn Atwal and Soumya Jain (2012) in the book entitled "The luxury market in India: Maharajas to Masses" mentions in the book that the strategies to direct the brands which enters the luxury market to have market share. In the same line, this study in the cult of the luxury brand: Inside Asia's love affair with luxury explores the emergence of luxury in the Asia region, people use to wear accessories which are highly expensive such as Rolex watches, Burberry bags and many more. This literature also mentions that Hong Kong posses more GUCCI and HERMES stores as compared to New York / Paris. In Asia, the cult of the luxury brand is so powerful that consumers account for as much as half of $\$ 80$ billion global luxe industry. In Tokyo, $95 \%$ of women owns Louis Vuitton bag in their 20s.

Oknokwo (2007) in the article entitled 'Luxury fashion branding: trends, tactics, techniques` discusses about all luxury fashion brands with year of establishments. This study mentions that it is impractical to discuss all the luxury brands in apparel category as the literature related to Luxury is limited.

\section{Luxury Marketing Mix}

This section addresses the second objective of this study i.e., Luxury Marketing mix which is prevailing in Luxury Brands in India as well as in foreign. The following are few paradox associated with luxury branding practices. 


\section{Product Dimension}

Kapferer and Bastien (2009, pp. 312) have mentioned in the study that luxury brands have to formulate strategy which is very different from the conventional marketing strategy for regular products. In this line, Products under luxury brands have to rely on specific identity which imbibes standards in it which converts the idea into symbolic representation in turn to product benefits or functionality of the product. This idea has to be adapted to new market with changing trends in the market. The policies pertaining to product impacts the quality as it is reinforced by packaging which is instrumental in communicating symbolic meaning (Fionda and Moore, 2009). Besides, Kapferer and Bastien (2009) argue that the DNA of luxury is the symbolic desire to belonging to Upper Class. Hence, luxury brands have to possess a high level of prestige. This study is in sync with Keller (2009, p.2) mentioned in the article entitled 'Managing the growth trade-off: Challenges and opportunities in luxury branding which describes Luxury branding typically to create many intangible brand associations and an aspirational image pertaining to the brands. Scholar feels that Luxury brand has an appeal especially to elite customers with many meanings attached to it. This study also quoted that many luxury brands reflect the rich heritage of a particular country.

\section{The Price Dimension}

The researcher believes that in most of the luxury brands, customers are emotionally attached to the product irrespective of price tags. In this line, Keller (2009) indicates in the study that luxury brands are unreasonable as it adopts superlative pricing strategy which makes brands less accessible and induce rarity. Hence, Luxury brands have to be careful in keeping their brand image intact without offering discounts.

\section{The Place Dimension}

Apart from pricing strategy, place or channel of distribution requires a specific marketing strategy for the luxury brands. There is a limited edition of sales as it is purchased by limited people who admire the brands as it is associated with their life and status.

In channel of distribution, luxury brands incorporate forward and backward integration. Forward integration includes developing own retail outlets and backward integration covers increasing control over the manufacturing process, for example by exchanging licenses with in-house manufacturing. Another advantage of integration is the increased control over product quality and brand image (Keller 2009, p. 292).

\section{Promotion Dimension}

Usually promotions are done in luxury brands catering to the limited people to express their extraordinary life and differentiate themselves. Many luxury fashion brands consider catwalk shows a vital communication tool for fostering their brand image and value. In this line, tools used in promotion includes celebrity endorsement (Fionda and Moore, 2009)

By constantly reviewing the literature, it is found that there is a clear difference between social classes and the consumption of luxury was limited to the elite classes. It dates back to nineteenth century that luxury goods sector came into being and the introduction of many of the highly valuable luxury brands that we know today, e.g. Hermes, Cartier and Louis Vuitton in France, Burberry in England and Bvlgare in Italy. 


\section{METHODOLOGY}

The study is descriptive and qualitative in nature in which secondary data was collated through available literatures in referred journals, market research agencies, luxury brand expert views in authenticated brand management journals, magazines and search engines.

\section{OBJECTIVES OF THE STUDY}

- To analyze the changing business patterns in Luxury Branding in terms of Luxury marketing mix

- Extending the same using e-business version of luxury branding practices

\section{LUXURY BRANDING PRACTICES IN INDIA}

Though Luxury retail market is still in nascent stage, India is geared up to face huge competition for luxury brands. Infact, this is exciting and challenging market which is evolving in Indian retail scene. It is evident that in Fashion and Apparel industry there is no dearth of designers, merchandisers and Fashion business managers, handicrafts and artisans in small scale businesses and most importantly the Luxury Brands across India has high craftsmanship, aesthetic appeal and exquisite products which is very Indian. In this line, luxury branding is not a new concept as it targets specialized customers or Elite customers and position its brand as highly distinct from others. It exhibits plethora of products which are very expensive affordable only by super rich people having common interest in buying luxury across the globe. In prevailing business situations, Luxury brands are gaining grounds in Luxury market especially in Fashion, Lifestyle and Apparel business. They maintain common standards across retail stores conveying brand image which should be consistent with prospect (Ailwadi, 2004). Apart from this, luxury brands provides customized product to people as per their requirement. This trend is very common among fashion industry in which the designers exhibit unconventional products which is a new phenomenon for many people.

Presently Indian Luxury market stands at \$18.4 billion which indicates that during the year 2015, brands such as Gucci, Christian Dior, Louis Vuitton, Canali India, LVMH India, Judith Leiber performed well (Euro Monitor, 2016). Similarly, the study made by ASSOCHAM in the year 2015 points out that luxury in jewels, SUV's, electronics and hotels, Apparels, accessories, wines and spirits have grown enormously. Besides there is increase in brand awareness and growing purchasing power of Upper class people in Tier-II and Tier-III cities. Apart from that, services such as fine dining, travel and luxury, jewellery is expected to grow at 36-percent over next three years. An interesting thing to be pointed out here is that many women's are working in different sectors; there is increase in purchasing power of women leading to huge demand for beauty products or cosmetics products. At the same time, it is evident that jewellery segment has outgrown to mention few companies are Titan Ltd., Gitanjali and P C Jewellers Ltd, have made it big in Top World's 50 luxury brands across the globe. Luxury offers exclusivity to customers who are elite i.e., size of Upper Income Group is the target market and study on luxury market indicates that 40-percent of their montly income on luxury brands whereas middle income group customers spend 10-percent of income on luxury brands.

Enlisted below are strategies adopted by luxury retailers. 
- Psychographic Segmentation: In Luxury branding, there are three levels of luxury brands which was proposed by Alleres (1990) in which super rich people are affordable to purchase the high end products which is inaccessible for an ordinary. Moreover, in India, there is changing perception in Luxury marketing arena which is evident that economic growth has generated more opportunities for the new generation where in plethora of merchandise are exhibited and new formats are emerging in luxury stores. At the same, time, double income families are emerging leading to increase in purchasing power and get accessed to luxury brands from the stores. (IMRB-International and the Confederation of Indian Industry)

- Technology driven Luxury Brands: Earlier, luxury brands used to be reluctant in adopting Click and Mortar model in which technology can be implemented to sell the brands virtually. In the current scenario of business, due to huge penetration of internet technology across various verticals of business, luxury brands started using e-business model i.e., Click and Mortar model which makes altogether customers feel a new experience. This transformation from Brick and Mortar into Click and Mortar is giving way for people to adopt social media. In Click and Mortar, Luxury web sites should be able to understand the customers buying behaviour and e-commerce features of privacy of data and coherency between luxury brands and the websites in order to develop the trust among customers

- Social Media: As technology is penetrated in every sphere of life so as in Luxury branding. Adopting Luxury brands in right social media, there can be high brand awareness in the minds of the people but some studies suggest that Luxury brands awareness should be less as it doesn't make sense for luxury brands to create high brand awareness among people as it is limited to very few people. In this line, Luxury brands can formulate strategy to select the right social media to their customers.

- Customization: Luxury retailers have adopted customizing their product which is generally a Label from famous fashion designers in which the products will be priced high and developed only for a particular person like Celebrity or well Known personality in India in accordance with their lifestyle.

\section{CONCLUSIONS}

This study addresses the broader insights into luxury branding. In the prevailing literatures on Luxury Branding, it was found that there is no specific definition of luxury brands and this study emphasizes on changing perception of the product based marketing mix. Besides, micro aspects of luxury brands to enhance their web presence.

It is a challenge for the luxury brands to create a trust among the customers as companies are transforming existing business model to online business models. In this line, the question arises is that whether the brands will be able to create a similar identity among the minds of customers or does it going to change?

\section{REFERENCES}

1. Arrigo, E. (2015). The role of the flagship store location in luxury branding. An international exploratory study. International Journal of Retail \& Distribution Management, 43(6), pp.518-537.

2. Atwal, G. and Khan, S. (2008) Luxury marketing in India: 'Because I'm worth it'. Admap, February: 36-38.

3. Bothra, N. Redefining Luxury Market in India: Contrasts, Contradictions and Extremes.

4. Choi, T. M. (2014). Fashion Branding and Consumer Behaviors. Springer New York. 
5. Dubois B., (1991), Qu"est ce que le luxe? Une analyse exploratoire de visuels publicitaires », Revue Française du Marketing, Vol.132, No.33, pp.55-64.

6. Fionda, A.M. \& Moore, C.M., 2009. The Anatomy of the Luxury Fashion Brand. Journal of Brand Management, 16(5-6), pp.347-363.

7. Geerts, Angy and Veg-Sala, Nathalie, Evidence on Internet Communication Management Strategies for Luxury Brands (2011). Global Journal of Business Research, Vol. 5, No. 5, pp. 81-94, 2011.

8. Geerts, Angy and Veg-Sala, Nathalie, Evidence on Internet Communication Management Strategies for Luxury Brands (2011). Global Journal of Business Research, Vol. 5, No. 5, pp. 81-94, 2011.

9. https://portfolio.pearlacademy.com/assets/site/images/student/POTENTIAL_OF_LUXURY_BRANDS_IN_TIER_I_AND_TIER _II_CITIES1.pdf

10. Keller, K. L. (2017). Managing the growth tradeoff: Challenges and opportunities in luxury branding. In Advances in Luxury Brand Management. Palgrave Macmillan, Cham, pp.179-198

11. Kratz, C., \& Bruce, M. (2007). Competitive marketing strategies of luxury fashion companies. In Fashion marketing (pp. 154174). Routledge.

12. Manlow, V. (2011). Creating an American mythology: A comparison of branding strategies in three fashion firms. Fashion Practice, 3(1), pp.85-109.

13. Oeppen, J., \& Jamal, A. (2014). Collaborating for success: Managerial perspectives on co-branding strategies in the fashion industry. Journal of Marketing Management, 30(9-10), pp.925-948.

14. Okonkwo, U. (2009). Sustaining the luxury brand on the Internet. Journal of brand management, 16(5-6), 302-310.

15. Patil, S., \& Handa, A. Counterfeit Luxury Brands Scenario in India: An Empirical Review.

16. Phau I. and Prendergast G., (2000). Consuming luxury brands: The relevance of the 'Rarity Principle, The Journal of Brand Management, 8(2), pp. 122-138.

17. Rekha, U., \& Pramod, M. Alternate Modes of Corporate Brand Endorsement: Need of the Hour in Indian Context.

18. Turkeshi, N., \& Sela, N. The Role and the Importance of the Brand in the Development of the Enterprises.

19. Vickers, S. J. and Renand, F. (2003) The marketing of luxury goods: An exploratory study-three conceptual dimensions. The Marketing Review, 3(4), pp. 459-478.

20. Vigneron, F. and Johnson, L. W. (2004) Measuring perceptions of brand luxury. Brand Management 11 (6), pp. $484-506$. 